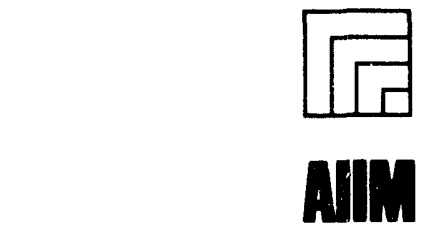

Association for Information and Image Management

1100 Wayne Avenue, Suite 1100

Silver Spring. Maryland 20910

301/587-8202

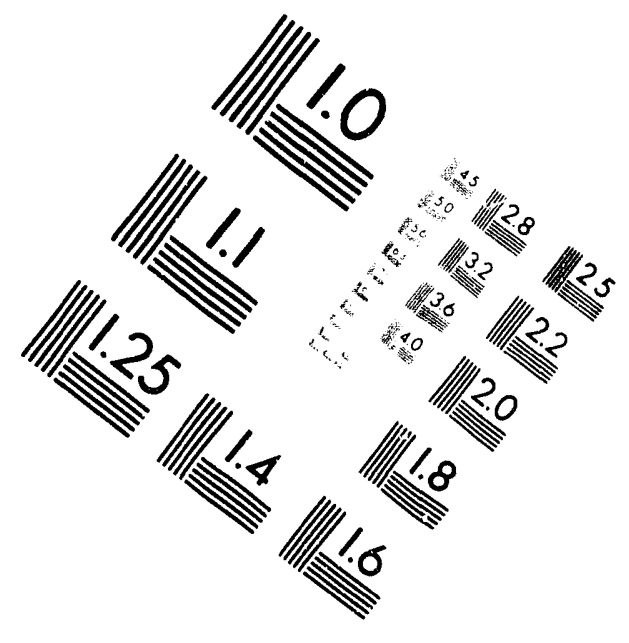

\title{
Centimeter
}

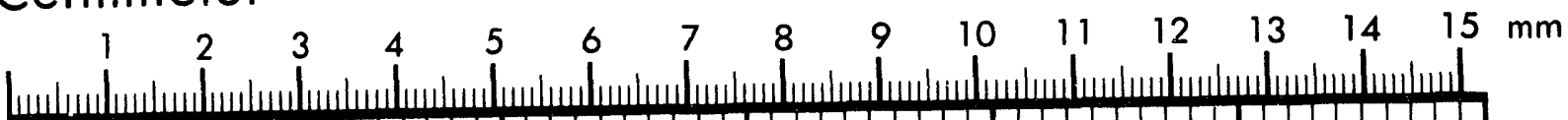

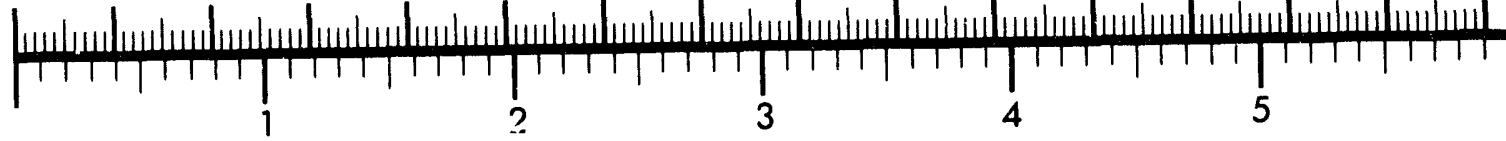

Inches
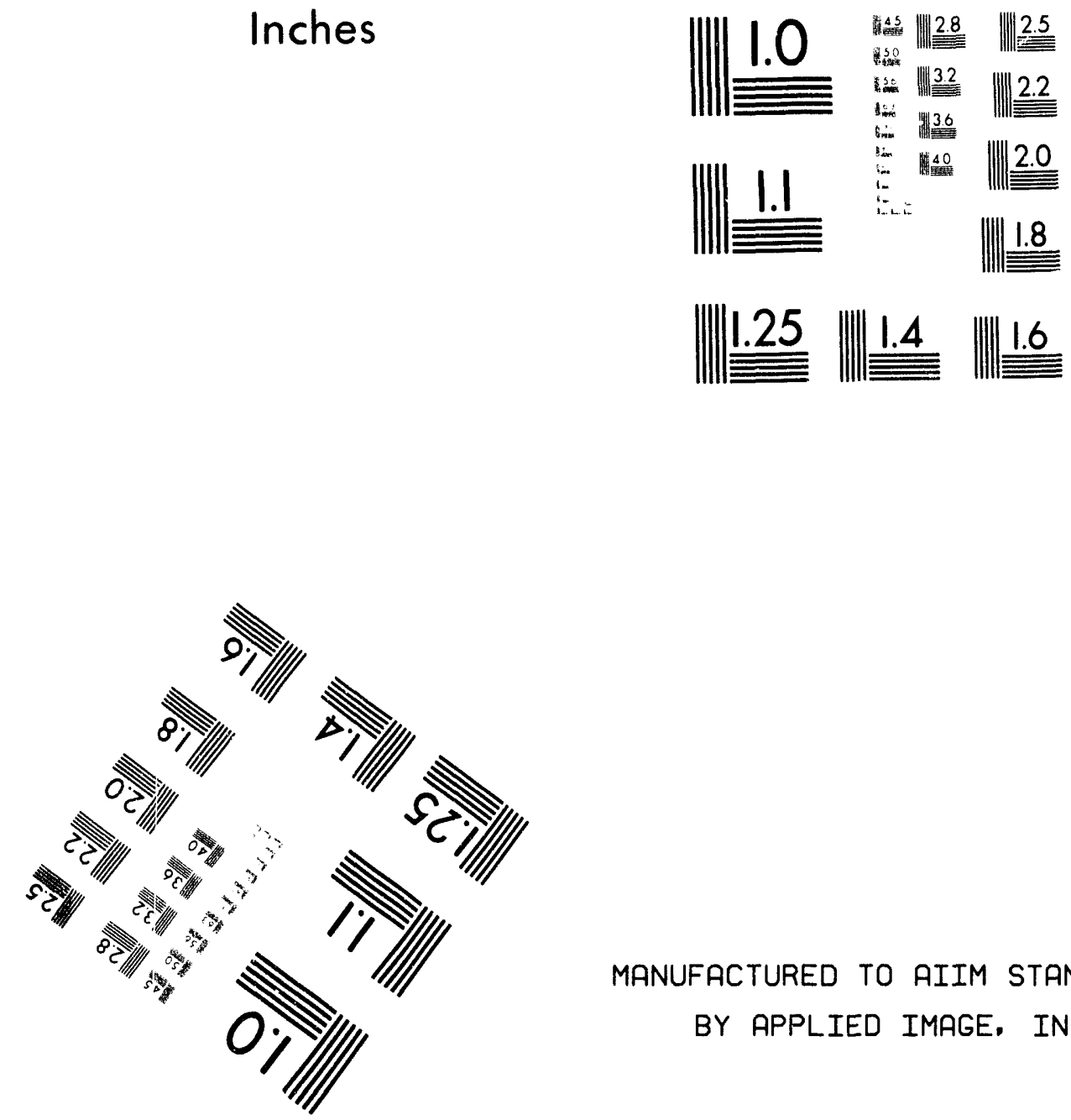

MANUFACTURED TO AIIM STANDARDS

BY APPLIED IMAGE, INC.

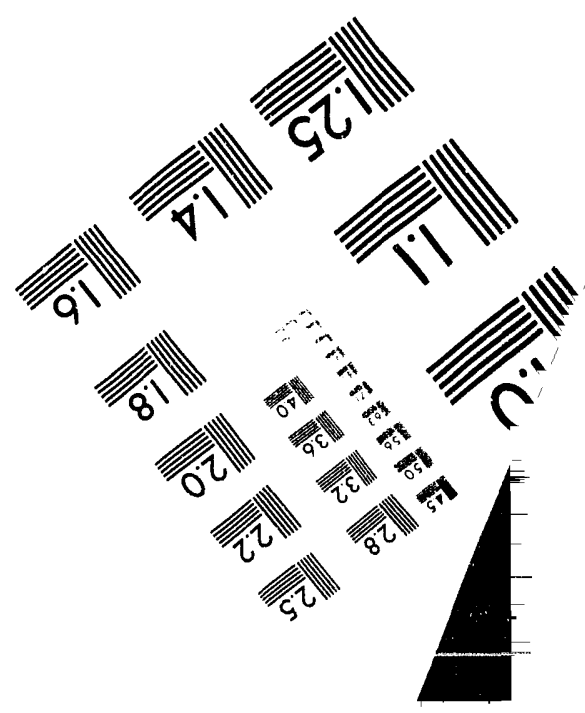



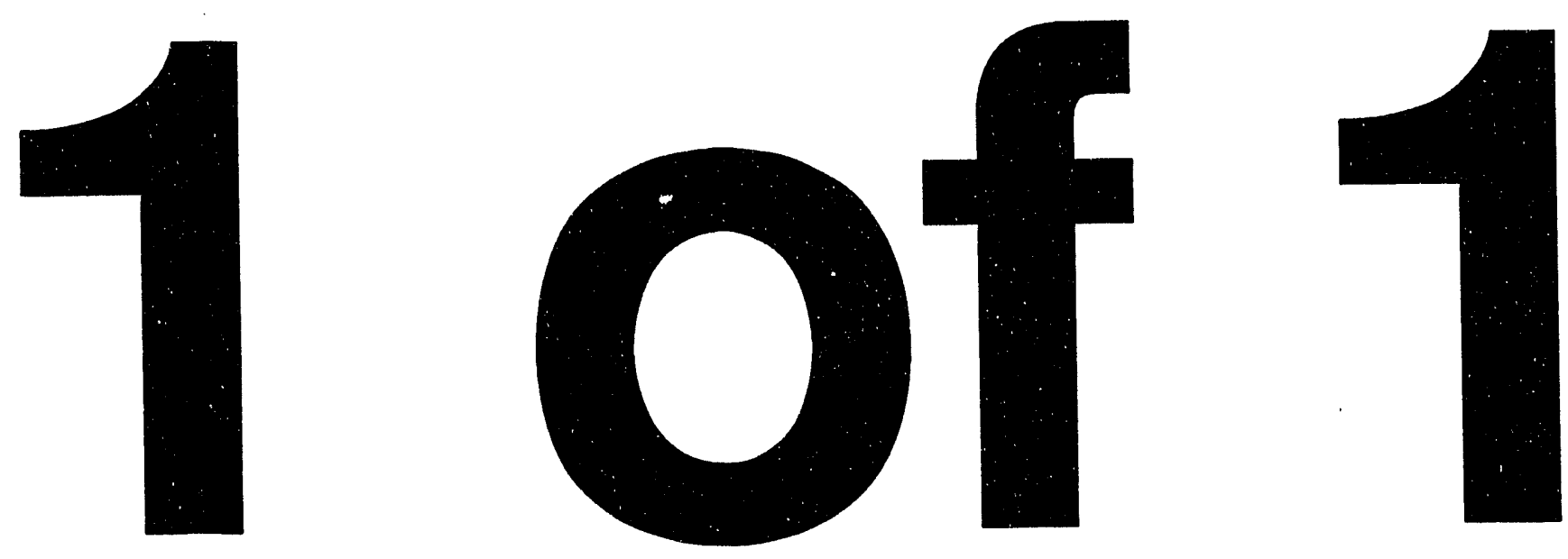
Argonne National Laboratory

9700 South Cass Avenue, Argonne, Illinois 60439

\section{DERIVATION OF URANIUM RESIDUAL RADIOACTIVE MATERIAL GUIDELINES FOR THE ALIQUIPPA FORGE SITE}

by

F. Monette, L. Jones, and C. Yu

Environmental Assessment and Information Sciences Division

September 1992

work sponsored by

U.S. Department of Energy DOE Field Office

Former Sites Restoration Division

Oak Ridge, Tennessee

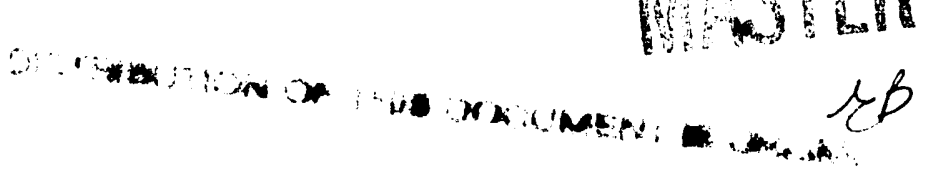




\section{CONTENTS}

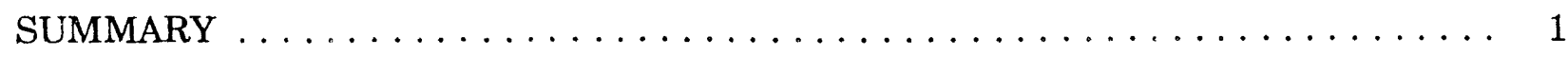

1 INTRODUCTION AND BRIEF HISTORY $\ldots \ldots \ldots \ldots \ldots \ldots \ldots \ldots \ldots \ldots$

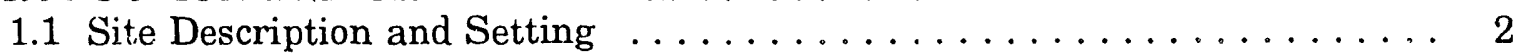

1.2 Site History . . . . . . . . . . . . . . . . . . . . . . . 2

1.3 Derivation of Cleanup Guidelines $\ldots \ldots \ldots \ldots \ldots \ldots \ldots \ldots \ldots$

2 SCENARIO DEFINITIONS $\ldots \ldots \ldots \ldots \ldots \ldots \ldots \ldots \ldots \ldots \ldots$

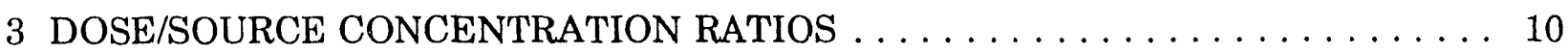

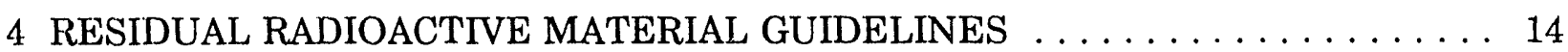

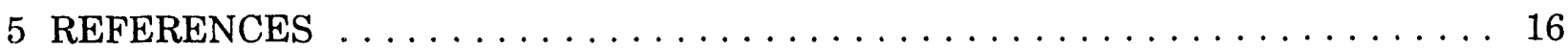

Appendix: Parameters Used in the Analysis of the Aliquippa Forge Site $\ldots \ldots \ldots 17$

\section{TABLES}

1 Summary of Pathways for Scenarios A, B, C, and D at the Aliquippa Forge Site . . . . . . . . . . . . . . . . . 9

2 Maximum Dose/Source Concentration Ratios for Scenario A at the Aliquippa Forge Site . . . . . . . . . . . . . . . . . 11

3 Maximum Dose/Source Concentration Ratios fcr Scenario B at the Aliquippa Forge Site $\ldots \ldots \ldots \ldots \ldots \ldots \ldots \ldots \ldots \ldots \ldots \ldots$

4 Maximum Dose/Source Concentration Ratios for Scenario C

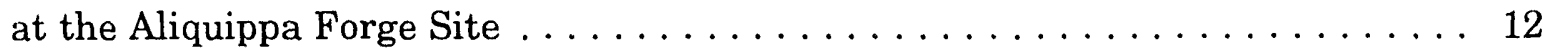

5 Maximum Dose/Source Concentration Ratios for Scenario D

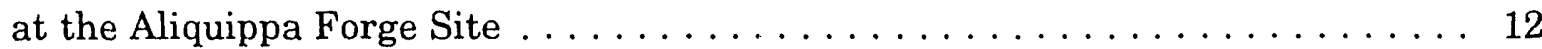

6 Total Dose/Source Concentration Ratios for Uranium at the Aliquippa Forge Site $\ldots \ldots \ldots \ldots \ldots \ldots \ldots \ldots \ldots \ldots$

7 Residual Radioactive Material Guidelines for the Aliquippa Forge Site . . . . . . . . . . . . . . . . . . . . . 15

$8 \quad$ Ranges for Hot Spot Multiplication Factors $\ldots \ldots \ldots \ldots \ldots \ldots$

A.1 Parameters Used in the RESRAD Code for the Analysis of the Aliquippa Forge Site . . . . . . . . . . . . . . . . 17 


\section{FIGURES}

1 Location of the Aliquippa Forge Site $\ldots \ldots \ldots \ldots \ldots \ldots \ldots \ldots \ldots \ldots$

2 Site Map of the Aliquippa Forge Site $\ldots \ldots \ldots \ldots \ldots \ldots \ldots \ldots \ldots$ 


\section{DERIVATION OF URANIUM RESIDUAL RADIOACTIVE MATERIAL GUIDELINES FOR THE ALIQUIPPA FORGE SITE}

by

F. Monette, L. Jones, and C. Yu

\section{SUMMARY}

Residual radioactive material guidelines for uranium were derived for the Aliquippa Forge site in Aliquippa, Pennsylvania. This site has been identified for remedial action under the Formerly Utilized Sites Remedial Action Program (FUSRAP) of the U.S. Department of Energy (DOE). Tho uranium guidelines were derived on the basis of the requirement that the 50-year committed effective dose equivalent to a hypothetical individual who lives or works in the immediate vicinity of the Aliquippa Forge site should not exceed a dose of $100 \mathrm{mrem} / \mathrm{yr}$ following decontamination.

The DOE residual radioactive material guideline computer code, RESRAD, which implements the methodology described in the DOE manual for implementing residual radioactive material guidelines, was used in this evaluation. Four pritential scenarios were considered for the site; the scenarios vary with regard to time spent at the site, sources of water used, and sources of food consumed. The results of the evaluation indicate that the basic dose limit of $100 \mathrm{mrem} / \mathrm{yr}$ will not be exceeded for uranium (including uranium-234, uranium-235, and uranium-238) within 1,000 years, provided that the soil concentration of combined uranium (uranium-234, uranium-235, and uranium-238) at the Aliquippa Forge site does not exceed the following levels: $1,700 \mathrm{pCi} / \mathrm{g}$ for Scenario A (industrial worker: the expected scenario); 3,900 pCi/g for Scenario B (recreationist: a plausible scenario); $20 \mathrm{pCi} / \mathrm{g}$ for Scenario C (resident farmer using well water as the only water source: a possible but unlikely scenario), and $530 \mathrm{pCi} / \mathrm{g}$ for Scenario $\mathrm{D}$ (resident farmer using a distant water source not affected by site conditions as the only water source: a possible but unlikely scenario). The uranium guidelines derived in this report apply to the combined activity concentration of uranium-234, uranium-235, and uranium-238 and were calculated on the basis of a dose of $100 \mathrm{mrem} / \mathrm{yr}$. In setting the actual uranium guidelines for the Aliquippa Forge site, DOE will apply the as low as reasonably achievable (ALARA) policy to the decision-making process, along with other factors, such as whether a particular scenario is reasonable and appropriate and whether the contamination is isolated and localized. 


\section{INTRODUCTION AND BRIEF HISTORY}

The Formerly Utilized Sites Remedial Action Program (FUSRAP) was established in 1974 by the U.S. Atomic Energy Commission (AEC), a predecessor of the U.S. Department of Energy (DOE). The mandate of the program is to identify, evaluate, and, if necessary, decontaminate sites previously used by the AEC or its predecessor, the Manhattan Engineer District (MED).

The Aliquippa Forge site is located in Aliquippa, Pennsylvania. It was designated by DOE as a candidate for remedial action under FUSRAP, after Argonme National Laboratory (ANL) conducted a radiological survey of the site in 1978 (Bechtel National, Inc. [BNI] 1988). The proposed remedial action for the site will follow the guidelines established in DOE Order 5400.5 (DOE 1990). The RESRAD computer code (Gilbert et al. 1989) is used to derive residual radionuclide guidelines on a site-specific basis. This report presents the uranium guidelines derived for the Aliquippa Forge site on the basis of a dose limit of $100 \mathrm{mrem} / \mathrm{yr}$.

\subsection{SITE DESCRIPTION AND SETTING}

The Aliquippa Forge site is an industrial site located along the Ohio River in the town of Aliquippa, Pennsylvania, approximately $25 \mathrm{~km}$ (16 mi) northwest of Pittsburgh, Pennsylvania (Figure 1). The site is situated north of First Street between Route 51 and Beaver Avenue and covers an area of 3.2 ha ( 8 acres). The site became contaminated with radioactive materials in the late 1940 s when uranium was processed in a site building under contract with the AEC.

The property currently contains 10 buildings, 8 of which are interconnected; 2 water towers; a cooling tower; and a small cooling basin (Figure 2). The site is fenced on the east and north sides; however, access can be gained to the south and west sides of the property. The site is generally level, sloping on the east side into a small creek, with large weeds and small brush surrounding the buildings (BNI 1991). The nearest residential community is

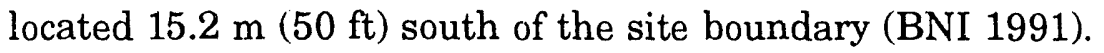

The mean annual temperature of the Pittsburgh area is approximately $10^{\circ} \mathrm{C}\left(50^{\circ} \mathrm{F}\right)$; January is the coldest month $\left(-3^{\circ} \mathrm{C}\left[27^{\circ} \mathrm{F}\right]\right)$ and July is the warmest $\left(22^{\circ} \mathrm{C}\left[71^{\circ} \mathrm{F}\right]\right)$. Precipitation averages $92 \mathrm{~cm}$ (36 in.) annually; the relative humidity averages $68 \%$ (NOAA 1982).

\subsection{SITE HISTORY}

From July 1948 to late 1949, Building 3 of the Vulcan Crucible Steel Company, a previous owner of the site, was used for uranium-rolling operations under contract with the AEC. The Vulcan facility received uranium billets from various sources and rolled them into 


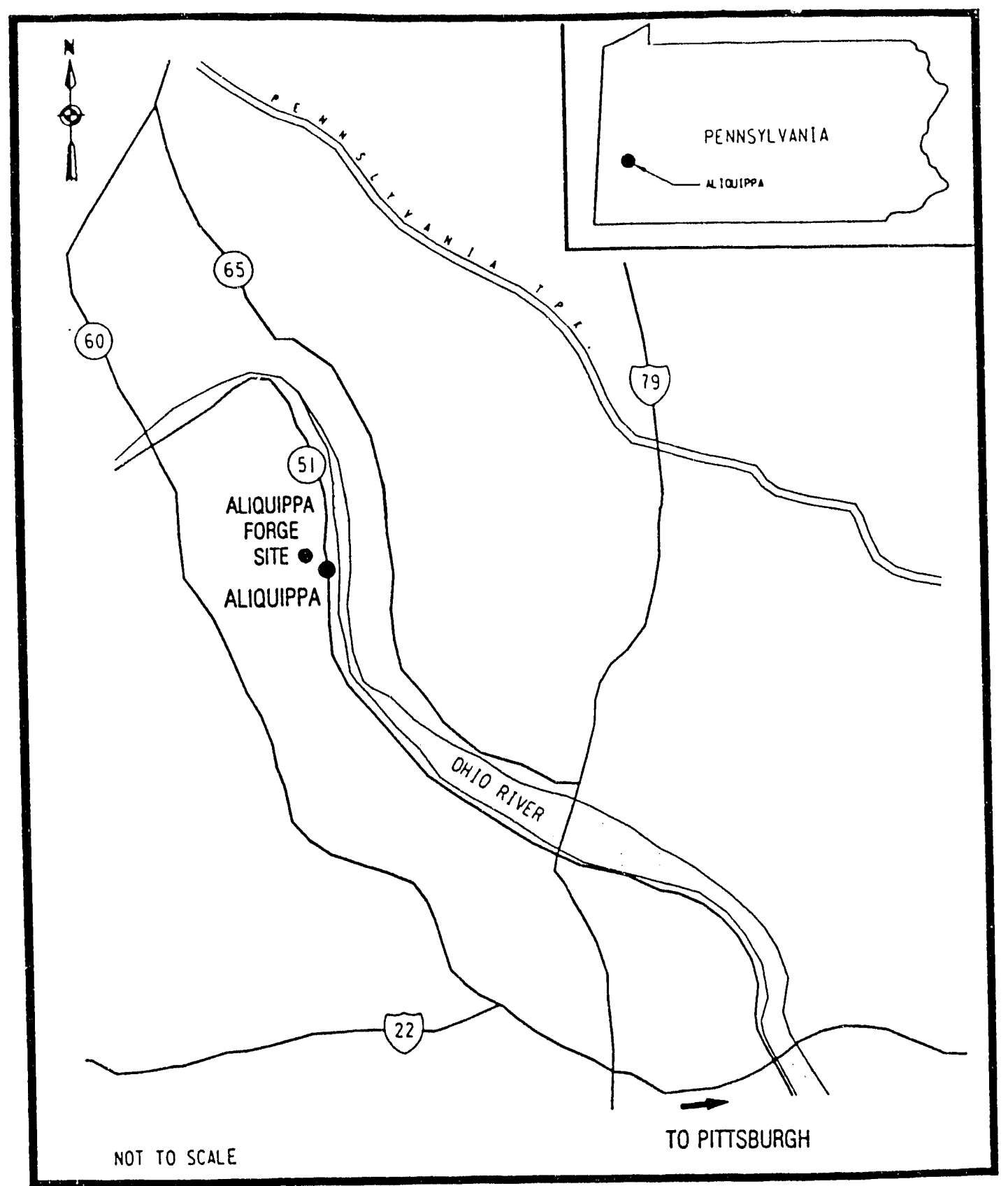

FIGURE 1 Location of the Aliquippa Forge Site (Source: BNI 1991) 


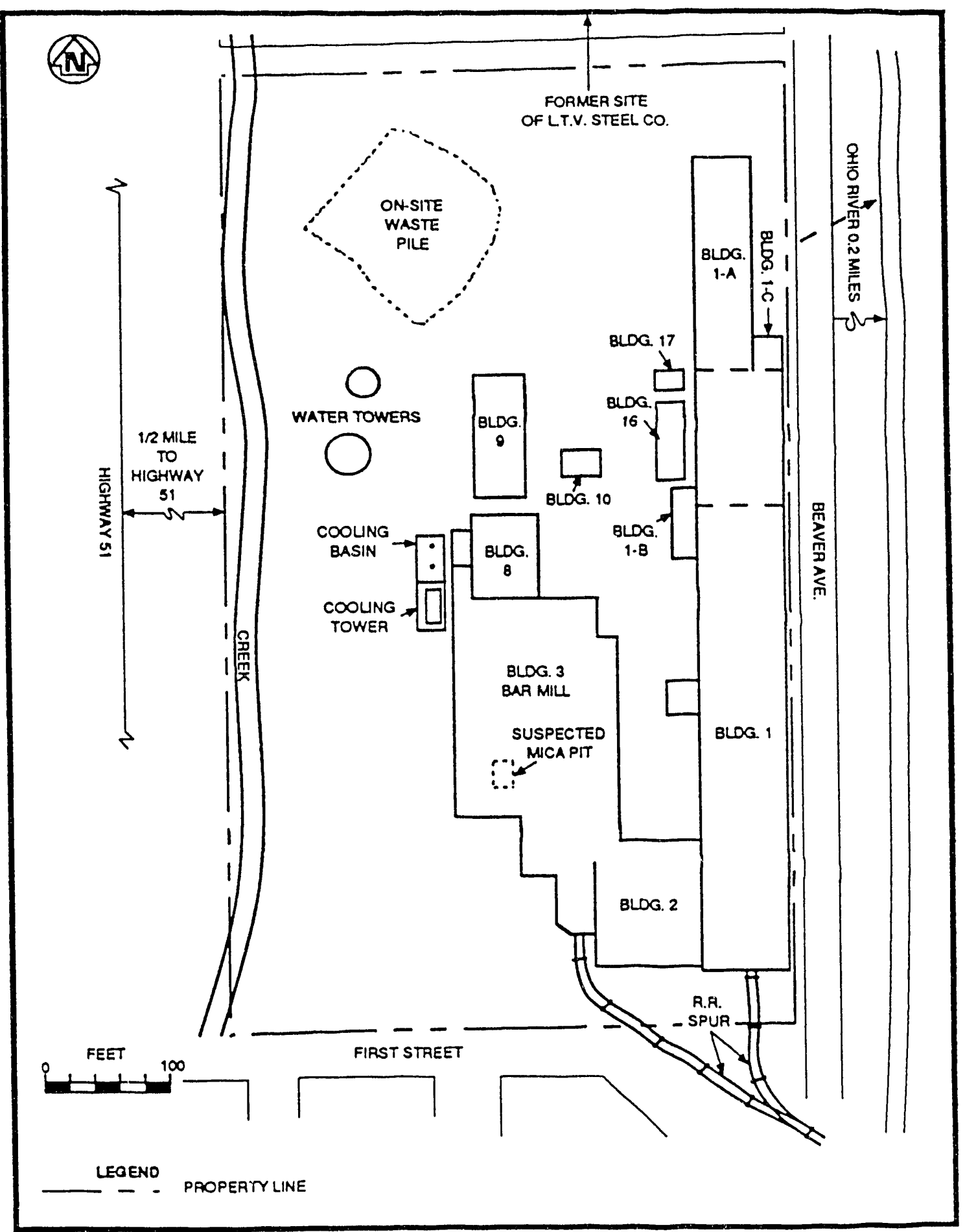

FIGURE 2 Site Map of the Aliquippa Forge Site (Source: BNI 1991) 
rods. The billets measured 45 to $61 \mathrm{~cm}(1.5$ to $2 \mathrm{ft}$ ) in length and 10 to $13 \mathrm{~cm}$ ( 4 to 5 in.) in diameter; they weighed from 44 to $100 \mathrm{~kg}$ (120 to $270 \mathrm{lb})$. During the rolling operation, the billets were formed into rods $5.5 \mathrm{~m}(18 \mathrm{ft})$ in length and $3.8 \mathrm{~cm}$ (1.5 in.) in diameter. Finished rods were boxed and shipped to other AEC facilities. After operations ceased, a decontamination effort was conducted in 1950.

Currently, the site is not being used. Access to Building 3 can easily be gained from several areas. Building 3 is a sheet metal structure with portions of the roof missing. The building measures $110 \times 43 \mathrm{~m}(360 \times 140 \mathrm{ft})$ and contains two furnaces for heating billets, a rolling mill, and cutting and extruding equipment. The floor consists of sections of concrete (poured at different times), brick over dirt, bare dirt, and steel plates.

In 1978, a radiological survey conducted by ANL identified the presence of radioactive contamination in and around Building 3 (ANL 1982). The contamination, principally normal uranium-238, was found on the floors, walls, and overhead beams above the furnaces that were used for heating billets. In addition, some contaminated steel flooring was found outside the building in the vicinity of the conling basin. The maximum contact exposure rate measured within Building 3 was $2 \mathrm{mR} / \mathrm{h}$ on the dirt floor. Indoor radon and radon daughter concentrations were measured and were within the range of background levels $(1 \mathrm{pCi} / \mathrm{L})$. Uranium concentrations in soil samples taken adjacent to Building 3 exceeded background levels and ranged from 0.3 to $109 \mathrm{pCi} / \mathrm{g}$. Uranium contamination was judged to be limited to the top $0.5 \mathrm{~m}$ ( $2 \mathrm{ft}$ ) of soil. Consequently, the site was designated in August 1983 to be remediated under FUSRAP.

A follow-up radiological survey was conducted in 1987 at the request of the site owner to determine whether Building 3 was suitable for leased storage space (BNI 1988). The results of this survey indicated spotty uranium contamination in approximately $43 \%$ of the building.

In 1988, BNI conducted an interim remedial action effort in Building 3 to allow restricted use by Aliquippa Forge, Inc. (Harbert 1989). Most of the building was decontaminated by direct removal of contaminated materials; the remaining contaminated area $\left(232 \mathrm{~m}^{2}\left[2,500 \mathrm{ft}^{2}\right]\right)$ was fenced to restrict access. Remaining areas of known contamination include the fenced area, walls from $2 \mathrm{~m}(6 \mathrm{ft})$ to the ceiling, two furnaces, structural steel and ceiling surfaces, and soil in two localized areas outside of the building.

Currently, a comprehensive field sampling effort is planned in order to further delineate the known contaminated areas, investigate decontaminated areas for recontamination, and spot check other areas of the site for contamination (BNI 1991). Preliminary analysis of soil samples indicates that uranium-238 contamination ranges from 1.4 to $1,530 \mathrm{pCi} / \mathrm{g}$ outside the west loading dock door of Building 3, with maximum concentrations occurring in the top $30 \mathrm{~cm}$ (12 in.) of soil (Adams 1992). The total site area of $32,400 \mathrm{~m}^{2}\left(38,700 \mathrm{yd}^{2}\right)$ is used in this analysis to derive homogeneous soil guidelines for uranium. For a small isolated area of contamination (i.e., a hot spot), the hot spot guideline can be derived from the homogeneous guideline by using the hot spot multiplication factors described in Section 4 (Gilbert et al. 1989). 


\subsection{DERIVATION OF CLEANUP GUIDELINES}

Although most DOE cle anup guidelines applicable to remedial actions at FUSRAP sites are generic in nature (DOE 1990), uranium guidelines are derived on a site-specific basis. The purpose of this report is to present the derivation of the residual radioactive material guidelines for uranium (i.e., uranium-234, uranium-235, and uranium-238) that are applicable to remedial action at the Aliquippa Forge site; that is, the residual concentration of uranium in a homogeneously contaminated area that must not be exceeded if the site is to be released for use without radiological restrictions. On the assumption that uranium is the only radionuclide present at an above-background concentration, the derivation of sitespecific uranium guidelines for the Aliquippa Forge site was based on a dose limit of $100 \mathrm{mrem} / \mathrm{yr}$ (DOE 1990, 1992). The RESRAD computer code, which implements the methodoloyy described in the DOE manual for implementing residual radioactive material guidelines (Gilbert et al. 1989), was used to derive these guidelines. The DOE will establish the final uranium guidelines for the Aliquippa Forge site by applying the as low as reasonably achievable (ALARA) policy to the derived guidelines presented in this report, along with other factors, such as whether a particular scenario is reasonable and appropriate and whether the contamination is isolated and localized. 


\section{SCENARIO DEFINITIONS}

Four potential exposure scenarios were considered for the Aliquippa Forge site. In all scenarios it is assumed that, at some time within 1,000 years, the site will be released for use without radiological restrictions following decontamination.

Scenario A (the expected scenario) assumes industrial use of the site. A hypothetical person is assumed to work in the area of the site for 8 hours per day (6 hours outdoors and 2 hours indoors), 5 days per week, 50 weeks per year. The industrial worker does not ingest drinking water, plant foods, or fish from the decontaminated area, or ingest meat or milk from livestock raised in the decontaminated area.

Scenario B (a plausible scenario) assumes recreational use of the site. It is assumed that, at some time in the future, the site will be used as a public park. A hypothetical person spends 15 hours per week, 50 weeks per year in the decontaminated area of the park. The recreationist does not ingest drinking water, plant foods, or fish from the decontaminated area, or ingest meat or milk from livestock raised in the decontaminated area.

Scenario C (a possible but unlikely scenario) assumes the presence of a resident farmer in the immediate vicinity of the site who drinks water obtained from a well located at the downgradient edge of the decontaminated area, ingests plant foods grown in a garden in the decontaminated area, and ingests meat and milk from livestock raised in the decontaminated area. All water used by the farmer is drawn from the well. The individual also ingests fish taken from a pond adjacent to and downstream of the decontaminated area.

Scenario D (a possible but unlikely scenario) is identical to Scenario $\mathrm{C}$ but assumes that all water for the site comes from a distant source not affected by site conditions. Given the current industrial use of the site and the presence of the nearby Ohio River, it is unlikely that an on-site well would be the only source of water.

Potential radiation doses resulting from nine exposure pathways were analyzed: (1) direct exposure to external radiation from the decontaminated soil material, (2) internal radiation from inhalation of contaminated dust, (3) internal radiation from inhalation of emanating radon-222, (4) internal radiation from ingestion of plant foods grown in the decontaminated area and irrigated with water drawn from a well located at the downgradient edge of the decontaminated area, (5) internal radiation from ingestion of meat from livestock fed with fodder grown in the decontaminated area and water drawn from the wel!, (6) internal radiation from ingestion of milk from livestock fed with fodder grown in the decontaminated area and water drawn from the well, (7) internal radiation from ingestion of aquatic food (fish) from a pond, (8) internal radiation from drinking water drawn from the well, and (9) intornal radiation from incidental ingestion of soil. 
The RESRAD computer code, version 4.3 (Gilbert et al. 1989), was used to calculate the potential radiation doses to the hypothetical future industrial worker, recreationist, or resident farmer on the basis of the following assumptions:

- The resident farmer spends $50 \%$ of his or her time indoors in the decontaminated area, $25 \%$ outdoors in the decontaminated area, and $25 \%$ away from the decontaminated area. The industrial worker spends 2,000 hours per year on-site (25\% indoors and $75 \%$ outdoors). The recreationist spends 750 hours per year on-site, all outdoors.

- The walls, floor, and foundation of the house or office building reduce external exposure by $30 \%$; the indoor dust level is $40 \%$ of the outdoor dust level (Gilbert et al. 1989).

- The depth of the house or building foundation is $1 \mathrm{~m}(3 \mathrm{ft})$ below ground surface, with an effective radon diffusion coefficient of $2 \times 10^{-8} \mathrm{~m}^{2} / \mathrm{s}$.

- The size of the decontaminated area is large enough that $50 \%$ of the plant food diet consumed by the resident farmer is grown in a garden in the decontaminated area. The industrial worker or recreationist does not consume these plant foods.

- The size of the decontaminated area is large enough to provide sufficient meat and milk for the resident farmer from livestock raised (i.e., foraged) in the decontaminated area. The industrial worker or recreationist does not consume this meat or milk.

- Vegetables are irrigated by and livestock are provided with water drawn from the well located adjacent to the decontaminated area (Scenario C). For Scenario D, all water comes from a distant source unaffected by site conditions.

- The adjacent pond provides $50 \%$ of the aquatic food consumed by the resident farmer (Scenario C). The industrial worker, recreationist, or resident farmer (Scenario $D$ ) does not consume any aquatic food from the decontaminated area.

- The adjacent well provides $100 \%$ of the drinking water consumed by the resident farmer (Scenario C). For Scenario D, all drinking water comes from a distant source unaffected by site conditions. In addition, the industrial worker or recreationist does not consume drinking water from an on-site well.

- After remedial action, no cover material is placed over the decontaminated area. 
- Hydrogeologic properties of the Aliquippa Forge site were taken from a summary report provided by Bechtel/Geotechnical Services (Kautz 1992). The following data were obtained from the summary report: hydraulic gradient for the saturated zone; hydraulic conductivity for the contaminated, unsaturated, and saturated zones; porosity of the contaminated, unsaturated, and saturated zones; thickness of the un'saturated zone; density of the contaminated, unsaturated, and saturated zones; and sitespecific distribution coefficients for uranium. Approximations of the water table drop rate and the contaminated zone erosion rate were taken from a nearby site in Canonsburg, Pennsylvania (DOE 1983a,b). The Canonsburg site is located about 30 miles from the Aliquippa Forge site.

All pathways considered for Scenarios A, B, C, and D are summarized in. Table 1.

TABLE 1 Summary of Pathways for Scenarios A, B, C, and D at the Aliquippa Forge Site

\begin{tabular}{|c|c|c|c|c|}
\hline Pathway & Scenario A & Scenario B & Scenario C & Scenario D \\
\hline External exposure & Yes & Yes & Yes & Yes \\
\hline Inhalation & Y ss & Yes & Yes & Yes \\
\hline Radon & Yes & Yes & Yes & Yes \\
\hline Ingestion of soil & Yes & Yes & Yes & Yes \\
\hline Ingestion of plant foods & No & No & Yes & Yes \\
\hline Ingestion of meat & No & No & Yes & Yes \\
\hline Ingestion of milk & No & No & Yes & Yes \\
\hline Ingestion of fish & No & No & Yes & No \\
\hline Ingestion of water ${ }^{b}$ & No & No & Yes & No \\
\hline
\end{tabular}

a Scenario A, industrial worker; Scenario B, recreationist; Scenario C, resident farmer using an on-site well as the only water source; Scenario $D$, resident farmer using a distant water source unaffected by site conditions.

b Source of water used: $100 \%$ well water for drinking, irrigation, and livestock for Scenario C; $100 \%$ distant source for drinking, irrigation, and livestock for Scenario D. 


\section{DOSE/SOURCE CONCENTRATION RATIOS}

The RESRAD computer code, version 4.3 (Gilbert et al. 1989), was used to calculate the dose/source concentration ratio $D S R_{i p}(t)$ for uranium isotope $i$ and pathway $p$ at time $t$ after decontamination. The time frame considered in this analysis was 1,000 years. Radioactive decay and ingrowth were considered in deriving the dose/source concentration ratios. The various parameters used in the RESRAD code for this analysis are listed in the Appendix. The calculated maximum dose/source concentration ratios for all pathways are presented in Tables 2 through 5 for Scenarios A, B, C, and D, respectively. For Scenarios A, $\mathrm{B}$, and $\mathrm{D}$, the maximum dose/source concentration ratios would occur at time zero (immediately after decontamination). For Scenario $\mathrm{C}$, the maximum dose/source concentration ratio for uranium isotopes would occur 90 years following decuntamination. The primary pathway for Scenarios A, B, and D would be inhalation for uranium-234 and uranium-238; external exposure is the primary pathway for uranium-235. The primary pat ${ }^{2}$ way for Scenario $\mathrm{C}$ is ingestion of groundwater for uranium-238, uraniu:n-234, and uranium-235. is,

The summation of $D S R_{i p}(t)$ for all pathways $p$ is the $D S R_{i}(t)$ for the $i$ th isotope, that

$$
\operatorname{DSR}_{i}(\mathrm{t})=\sum_{p} D S R_{i p}(t)
$$

The total dose/source concentration ratio for total uranium (enriched, depleted, or normal) can be calculated as

$$
\operatorname{DSR}(\mathrm{t})=\sum_{i} W_{i} D S R_{i}(t)
$$

where $W_{i}$ is the existing activity concentration fraction at the site for uranium-234, uranium-235, and uranium-238. For this analysis, $W_{i}$ is assumed $t \mathrm{t}$ be present in the natural activity concentration ratios of $1 / 2.046,1 / 2.046$, and $0.046 / 2.046$ for uranium-238, uranium-234, and uranium-235, respectively. The total dose/source concentration ratios for single nuclides and total uranium are provided in Taible 6 . These ratios were used to determine the allowable residual radioactivity for uranium at the Aliquippa Forge site. 
TABLE 2 Maximum Dose/Source Concentration Ratios for Scenario $A$ at the Aliquippa Forge Site

\begin{tabular}{|c|c|c|c|}
\hline \multirow[b]{2}{*}{ Pathway } & \multicolumn{3}{|c|}{$\begin{array}{c}\text { Maximum Dose/Source Concentration Ratio } \\
(\mathrm{mrem} / \mathrm{yr}) /(\mathrm{pCi} / \mathrm{g})^{\mathrm{a}}\end{array}$} \\
\hline & Uranium-234 & Uranium-235 & Uranium-238 \\
\hline External exposure & $2.9 \times 10^{-4}$ & $1.9 \times 10^{-1}$ & $2.7 \times 10^{-2}$ \\
\hline Inhalation & $4.2 \times 10^{-2}$ & $3.8 \times 10^{-2}$ & $3.8 \times 10^{-2}$ \\
\hline Radon & 0 & 0 & 0 \\
\hline Ingestion of soil & $1.8 \times 10^{-3}$ & $1.8 \times 10^{-3}$ & $1.8 \times 10^{-3}$ \\
\hline Ingestion of plant foods & 0 & 0 & 0 \\
\hline Ingestion of meat & 0 & 0 & 0 \\
\hline Ingestion of milk & 0 & 0 & 0 \\
\hline Ingestion of fish & 0 & 0 & 0 \\
\hline Ingestion of water & 0 & 0 & 0 \\
\hline
\end{tabular}

a Maximum dose/source concentration ratios would occur at time zero (immediately following decontamination); all values are reported to two significant figures.

TABLE 3 Maximum Dose/Source Concentration Ratios for Scenario $B$ at the Aliquippa Forge Site

\begin{tabular}{lccc}
\hline & \multicolumn{3}{c}{\begin{tabular}{c} 
Maximum \\
\multicolumn{1}{c}{ Path way } \\
Pare/Source Concentration Ratio \\
(mrem/yr)/(pCi/g)
\end{tabular}} \\
\cline { 2 - 4 } & Uranium-234 & Uranium-235 & Uranium-238 \\
\hline External exposure & $1.2 \times 10^{-4}$ & $7.9 \times 10^{-2}$ & $1.1 \times 10^{-2}$ \\
Inhalation & $1.9 \times 10^{-2}$ & $1.7 \times 10^{-2}$ & $1.7 \times 10^{-2}$ \\
Radon & 0 & 0 & 0 \\
Ingestion of soil & $8.2 \times 10^{-4}$ & $7.9 \times 10^{-4}$ & $7.9 \times 10^{-4}$ \\
Ingestion of plant foods & 0 & 0 & 0 \\
Ingestion of meat & 0 & 0 & 0 \\
Ingestion of milk & 0 & 0 & 0 \\
Ingestion of fish & 0 & 0 & 0 \\
Ingestion of water & 0 & 0 & 0 \\
\hline
\end{tabular}

a Maximum dose/source concentration ratios would occur at time zero (immediately following decontamination); all values are reported to two significant figures. 
TABLE 4 Maximum Dose/Source Concentration Ratios for Scenario C at the Aliquippa Forge Site ${ }^{a}$

\begin{tabular}{lccc}
\hline & \multicolumn{3}{c}{ Maximum $\begin{array}{c}\text { Dose/Source Concentration Ratio } \\
(\mathrm{mrem} / \mathrm{yr}) /(\mathrm{pCi} / \mathrm{g})^{\mathrm{b}}\end{array}$} \\
\cline { 2 - 4 } \multicolumn{1}{c}{ Pathway } & Uranium-234 & Uranium-235 & Uranium-238 \\
${$\cline { 2 - 4 }$} }$ & $2.8 \times 10^{-5}$ & $1.0 \times 10^{-3}$ & $1.2 \times 10^{-4}$ \\
Inhalation & $1.8 \times 10^{-4}$ & $7.4 \times 10^{-4}$ & $1.4 \times 10^{-4}$ \\
Radon & $1.4 \times 10^{-6}$ & 0 & $4.5 \times 10^{-11}$ \\
Ingestion of soil & $7.8 \times 10^{-6}$ & $5.5 \times 10^{-5}$ & $6.3 \times 10^{-6}$ \\
Ingestion of plant foods & $4.1 \times 10^{-1}$ & $4.0 \times 10^{-1}$ & $3.9 \times 10^{-1}$ \\
Ingestion of meat & $4.6 \times 10^{-1}$ & $4.4 \times 10^{-1}$ & $4.4 \times 10^{-1}$ \\
Ingestion of milk & $1.2 \times 10^{-1}$ & $1.1 \times 10^{-1}$ & $1.1 \times 10^{-1}$ \\
Ingestion of fish & $8.7 \times 10^{-3}$ & $9.6 \times 10^{-3}$ & $8.3 \times 10^{-3}$ \\
Ingestion of water & 4.2 & 4.1 & 4.1 \\
\hline
\end{tabular}

a Scenario C assumes that all water is derived from an on-site well. Given the current industrial use of the site and the presence of the nearby Ohio River, this scenario is considered highly unlikely for this site.

b Maximum dose/source concentration ratios would occur 90 years following decontamination; all values are reported to two significant figures.

TABLE 5 Maximum Dose/Source Concentration Ratios for Scenario D at the Aliquippa Forge Site

Maximum Dose/Source Concentration Ratio $(\mathrm{mrem} / \mathrm{yr}) /(\mathrm{pCi} / \mathrm{g})^{\mathrm{b}}$

\begin{tabular}{lccc}
\cline { 2 - 4 } \multicolumn{1}{c}{ Pathway } & Uranium-234 & Uranium-235 & Uranium-238 \\
\hline External exposure & $8.2 \times 10^{-4}$ & $5.5 \times 10^{-1}$ & $7.8 \times 10^{-2}$ \\
Inhalation & $9.7 \times 10^{-2}$ & $8.9 \times 10^{-2}$ & $8.9 \times 10^{-2}$ \\
Radon & 0 & 0 & 0 \\
Ingestion of soil & $4.3 \times 10^{-3}$ & $4.1 \times 10^{-3}$ & $4.1 \times 10^{-3}$ \\
Ingestion of plant foods & $3.2 \times 10^{-2}$ & $-0 \times 10^{-2}$ & $3.0 \times 10^{-2}$ \\
Ingestion of meat & $7.9 \times 10^{-3}$ & $7.6 \times 10^{-3}$ & $7.6 \times 10^{-3}$ \\
Ingestion of milk & $1.1 \times 10^{-3}$ & $1.1 \times 10^{-3}$ & $1.1 \times 10^{-3}$ \\
Ingestion of fish & 0 & 0 & 0 \\
Ingestion of water & 0 & 0 & 0 \\
\hline
\end{tabular}

a Scenario D assumes that all water comes from a distant source unaffected by site conditions.

b Maximum doseisource concentration ratios would occur at time zero (immediately following decontamination); all values are reported to two significant figures. 
TABLE 6 Total Dose/Source Concentration Ratios for Uranium at the Aliquippa Forge Site

\begin{tabular}{lcccc}
\hline & \multicolumn{4}{c}{ Total $\begin{array}{c}\text { Dose/Source Concentration Ratio } \\
(\mathrm{mrem} / \mathrm{yr}) /(\mathrm{pCi} / \mathrm{g})^{\mathrm{a}}\end{array}$} \\
\cline { 2 - 5 } & \multicolumn{4}{c}{. } \\
\cline { 2 - 5 } Radionuclide & Scenario A & Scenario B & Scenario C & Scenario D \\
\hline & & & & \\
Uranium-234 & $4.4 \times 10^{-2}$ & $2.0 \times 10^{-2}$ & 5.2 & $1.4 \times 10^{-1}$ \\
Uranium-235 & $2.3 \times 10^{-1}$ & $9.7 \times 10^{-2}$ & 5.1 & $6.8 \times 10^{-1}$ \\
Uranium-238 & $6.7 \times 10^{-2}$ & $2.9 \times 10^{-2}$ & 5.0 & $2.1 \times 10^{-1}$ \\
Total Uranium & $5.9 \times 10^{-2}$ & $2.6 \times 10^{-2}$ & 5.1 & $1.9 \times 10^{-1}$ \\
\hline
\end{tabular}

a All values are reported to two significant figures. 


\section{RESIDUAL RADIOACTIVE MATERIAL GUIDELINES}

The residual radioactive material guideline is the concentration of residual radioactive material that can remain in a decontaminated area and still allow use of the area without radiological restrictions. Given the DOE annual radiation dose limit of $100 \mathrm{mrem} / \mathrm{yr}$ for an individual (DOE 1990, 1992), the residual radioactive material guideline, G, for uraniuin at the Aliquippa Forge site can be calculated as

$$
G=100 / D S R
$$

where $D S R$ is the total dose/source concentration ratio listed in Table 6. The calculated residual radioactive material guidelines for individual radionuclides (uranium-234, uranium-235, and uranium-238) and total uranium are presented in Table 7.

In the calculation of the total uranium guidelines (reported to two significant figures), it was assumed that the activity concentration ratio of uranium-238, uranium-234, and uranium-235 is 1:1:0.046. The derived guidelines for total uranium would be 1,700, $3,900,20$, and $530 \mathrm{pCi} / \mathrm{g}$ for Scenarios A, B, C, and D, respectively. If uranium-238 is measured as the indicator radionuclide, then the uranium-238 limits for total uranium can be calculated by dividing the total uranium guidelines by 2.046 . The resulting limits would be $830,1,900,10$, and $260 \mathrm{pCi} / \mathrm{g}$ for Scenarios A, B, C, and D, respectively.

In implementation of the derived radionuclide guidelines for decontamination of a site, the law of sum of fractions applies. That is, the summation of the fractions of radionuclide concentrations $S_{i}$ remaining on-site, averaged over an area of $100 \mathrm{~m}^{2}\left(120 \mathrm{yd}^{2}\right)$ and a depth of $15 \mathrm{~cm}\left(6 \mathrm{in}\right.$.) and divided by its guideline $G_{i}$ should not be greater than unity:

$$
\sum_{i} S_{i} / G_{i} \leq 1
$$

The derived guidelines are for a large, homogeneously contaminated area. For an isolated, small area of contamination, that is, a hot spot, the allowable concentration that can remain on-site may be higher than the homogeneous guideline, depending on the size of the area of contamination and in accordance with Table 8. 
TABLE 7 Residual Radioactive Material Guidelines for the Aliquippa Forge Site

\begin{tabular}{lcccc}
\hline & \multicolumn{4}{c}{ Guideline $(\mathrm{pCi} / \mathrm{g})^{\mathrm{a}}$} \\
\cline { 2 - 5 } Radionuclide & Scenaric A & Scenario B & Scenario C & Scenario D \\
\hline & & & & \\
Uranium-234 & 2,300 & 5,100 & 19 & 710 \\
Uranium-235 & 430 & 1,000 & 20 & 150 \\
Uranium-238 & 1,500 & 3,400 & 20 & 480 \\
Total Uranium & 1,700 & 3,900 & 20 & 530 \\
\hline
\end{tabular}

a All values are reported to two significant figures.

TABLE 8 Ranges for Hot Spot Multiplication Factors

\begin{tabular}{lc}
\hline Range & $\begin{array}{c}\text { Factor } \\
\text { (multiple of } \\
\text { authorized limit) }\end{array}$ \\
\hline$<1 \mathrm{~m}^{2}$ & $10^{\mathrm{a}}$ \\
$1-<3 \mathrm{~m}^{2}$ & 6 \\
$3-<16 \mathrm{~m}^{2}$ & 3 \\
$10-25 \mathrm{~m}^{2}$ & 2 \\
\hline
\end{tabular}

a Areas less than $1 \mathrm{~m}^{2}$ are to be averaged over a $1-\mathrm{m}^{2}$ area, and that average shall not exceed 10 times the authorized limit.

Source: Gilbert et al. (1989). 


\section{REFERENCES}

Adams, W.C., 1992, "Aliquippa Forge Site Survey," letter from Adams (Health Physicist/ Project Leader, Environmental Survey and Site Assessment Program, Oak Ridge Associated Universities, Oak Ridge, Tenn.) to W.A. Williams (EM-421, U.S. Department of Energy, Washington, D.C.), July 15.

Argonne National Laboratory, 1982, Radiological Survey of Universal Cyclops, Inc., Titusville Plant (formerly Vulcan Crucible Steel) Aliquippa, Pennsylvania, May 2-8, 1978, report DOE-OHS/HP-82-104, Argonne, Ill.

Bechtel Nationa?. Inc. (BNI), 1988, Site Plan for Universal Cyclops, Aliquippa, Pennsylvania, report DOE/OR/20722-122, U.S. Department of Energy, Washington, D.C., Aug.

Bechtel National, Inc., 1991, Field Sampling Plan for the Aliquippa Forge Site, Aliquippa, Pennsylvania, report DOE/OR/20722-276, U.S. Department of Energy, Washington, D.C., March.

Gilbert, T.L., et al., 1989, A Manual for Implementing Residual Radioactive Material Guidelines, report ANL/ES-160, DOE/CH/8901, prepared by Argonne National Laboratory, Argonne, Ill., for U.S. Department of Energy, Assistant Secretary for Nuclear Energy, June.

Harbert, R.R., 1989, "Post-Remedial Action Summary of the Aliquippa Forge 1988 Decontamination of Building 3," letter from Harbert (Project Manager, Bechtel National, Inc., Oak Ridge, Tenn.) to W.M. Seay (Technical Services Division, Oak Ridge Operations Office, U.S. Department of Energy), May 16.

Kautz, S.A., 1992, techni-al memo from Kautz (Bechtel/Geotechnical Services, Oak Ridge, Tenn.) to L.G. Jones (Arg nne National Laboratory, Argonne, Ill.), March 4.

U.S. Department of Energy (DOE), 1983a, Remedial Actions at the Former Vitro Rare Metals Plant Site, Canonsburg, Washington County, Pennsylvania, report DOE/EIS-0096-F, Washington, D.C., July.

U.S. Department of Energy, 1983b, Remedial Action Plan for Stabilization of the Inactive Uranium Mill Tailings Site at Canonsburg, Pennsylvania, report UMTRA-DOE/AL-140, Washington, D.C., Oct.

U.S. Department of Energy, 1990, Radiation Protection of the Public and the Environment, DOE Order 5400.5, Washington, D.C., Feb. 8.

U.S. Department of Energy, 1992, Radiological Control Manual, report DOE/EH-0256T, Assistant Secretary for Environment, Safety and Health, Washington, D.C., June.

U.S. National Oceanic and Atmospheric Administration (NOAA), 1982, Climatography of the United States, No. 81, U.S. Department of Commerce, Washington, D.C., Sept. 
APPENDIX:

PARAMETERS USED IN THE ANALYSIS OF THE ALIQUIPPA FORGE SITE

The parametric values used in the RESRAD code for the analysis of the Aliquippa Forge site are listed in Table A.1. All parametric values are reported to three significant figures. Some parameters are specific to the Aliquip pa Forge site; other values are generic.

TABLE A.1 Parameters Used in the RESRAD Code for the Analysis of the Aliquippa Forge Site

\begin{tabular}{|c|c|c|c|c|c|}
\hline \multirow[b]{2}{*}{ Parameter } & \multicolumn{5}{|c|}{ Value } \\
\hline & Unit & Scenario A & Scenario B & Scenario C & Scenario i) \\
\hline Area of contaminated zone" & $\mathrm{m}^{2}$ & 32,400 & 32,400 & 32,400 & 32,400 \\
\hline Thickness of contaminated zone" & $\mathrm{m}$ & 0.5 & 0.5 & 0.5 & 0.5 \\
\hline Length parallel to aquifer flow" & $\mathrm{m}$ & not used & not used & 180 & 180 \\
\hline Cover depth & m & 0 & 0 & 0 & 0 \\
\hline Density of contaminated zone $e^{b}$ & $\mathrm{~g} / \mathrm{cm}^{3}$ & 1.6 & 1.6 & 1.6 & 1.6 \\
\hline Contaminated zone erosion rate & $\mathrm{m} / \mathrm{yr}$ & 0.002 & 0.002 & 0.002 & 0.002 \\
\hline Contaminated zone total porosity & $d^{d}$ & 0.4 & 0.4 & 0.4 & 0.4 \\
\hline Contaminated zone effective porosity & $\AA^{d}$ & 0.1 & 0.1 & 0.1 & 0.1 \\
\hline Contaminated zone hydraulic conductivity & $\mathrm{m} / \mathrm{yr}$ & 20 & 20 & 20 & 20 \\
\hline Contaminated zone b parameter & d & 5.3 & 5.3 & 5.3 & 5.3 \\
\hline Evapotranspiration coefficient & $\AA^{d}$ & 0.6 & 0.6 & 0.6 & 0.6 \\
\hline Precipitation & $\mathrm{m} / \mathrm{yr}$ & 0.92 & 0.92 & 0.92 & 0.92 \\
\hline Inigation & $\mathrm{m} / \mathrm{yr}$ & 0.2 & 0.2 & 0.2 & 0.2 \\
\hline Irrigation mode & $\AA^{4}$ & not used & not used & overhead & overhead \\
\hline Runoff coefficient &.$^{d}$ & 0.2 & 0.2 & 0.2 & 0.2 \\
\hline Watershed area for nearby pond & $\mathrm{m}^{2}$ & not used & not used & $1,000,000$ & $1 \times 10^{10}$ \\
\hline Density of saturated zone & $\mathrm{g} / \mathrm{cm}^{3}$ & 1.6 & 1.6 & 1.6 & 1.6 \\
\hline Saturated zone total porosity &.$d$ & not used & not used & 0.4 & 0.4 \\
\hline Saturated zone effective porosity &. & not used & not used & 0.1 & 0.1 \\
\hline Saturated zone hydraulic conductivity & $\mathrm{m} / \mathrm{yr}$ & not used & not used & 210 & 20 \\
\hline Saturated zone hydraulic gradient $t^{b}$ & $\therefore$ & not used & not used & 0.11 & 0.01 \\
\hline Saturated zone b parameter & .9 & 5.3 & 5.3 & 5.3 & 5.3 \\
\hline Water table drop rate & $\mathrm{m} / \mathrm{yr}$ & not used & not used & 0.002 & 0.002 \\
\hline $\begin{array}{l}\text { Well pump intake depth } \\
\text { (below water table) }\end{array}$ & $\mathrm{m}$ & not ised & not used & 10 & 10 \\
\hline $\begin{array}{l}\text { Model: nondispersion (ND) or } \\
\text { mass-balance }(\mathrm{MB})\end{array}$ & $A^{d}$ & not used & not used & ND & ND \\
\hline Number of unsaturated zone strata* &.$d$ & not used & not used & 1 & 1 \\
\hline unsaturated zone 1 thickness ${ }^{b}$ & $\mathrm{~m}$ & not used & not used & 2 & 2 \\
\hline unsaturated zone 1 soil density & $\mathrm{g} / \mathrm{cm}^{3}$ & not used & not used & 1.6 & 1.6 \\
\hline $\begin{array}{l}\text { unsaturated zone } 1 \text { total } \\
\text { porosity }\end{array}$ & $-d$ & not used & not used & 0.4 & 0.4 \\
\hline $\begin{array}{l}\text { unsaturated zone } 1 \text { effective } \\
\text { porosity }\end{array}$ & $-d$ & not used & not used & 0.1 & 0.1 \\
\hline $\begin{array}{l}\text { unsaturated zone } 1 \text { soil-specific } \\
\text { b parameter }\end{array}$ & $\therefore$ & not used & not used & 5.3 & 5.3 \\
\hline unsaturated zone 1 hydraulic & $\mathrm{m} / \mathrm{yr}$ & not used & $\mathrm{nc}$. usedf & 20 & 20 \\
\hline
\end{tabular}


TABLE A.1 (Cont.)

\begin{tabular}{|c|c|c|c|c|c|}
\hline \multirow[b]{2}{*}{ Parameter } & \multicolumn{5}{|c|}{ Value } \\
\hline & Unit & Scenario A & Scenario B & Scenario $\mathrm{C}$ & Scenario D \\
\hline \multicolumn{6}{|l|}{$\begin{array}{l}\text { Distribution coefficient } \\
\text { Contaminated zone }\end{array}$} \\
\hline $\begin{array}{l}\text { Uranium-234 }^{\mathrm{D}} \\
\text { Uranium-235 }\end{array}$ & & $\begin{array}{l}6 \\
6\end{array}$ & 6 & 6 & 6 \\
\hline Uranium-238 & & $\begin{array}{l}6 \\
6\end{array}$ & 6 & 6 & 6 \\
\hline Actinium-227 & & $\begin{array}{l}6 \\
20\end{array}$ & 6 & 6 & 6 \\
\hline Protactinium-231 ${ }^{\mathrm{f}}$ & & $\begin{array}{l}20 \\
50\end{array}$ & 20 & 20 & 20 \\
\hline Lead-210 & & $\begin{array}{r}50 \\
100\end{array}$ & 50 & 50 & 50 \\
\hline Radium-226 $6^{f}$ & & $\begin{array}{r}100 \\
70\end{array}$ & 100 & 100 & 100 \\
\hline Thorium-230 & & $\begin{array}{c}70 \\
60,000\end{array}$ & 70 & 70 & 70 \\
\hline \multirow{2}{*}{\multicolumn{6}{|c|}{$\begin{array}{l}\text { Thorium-230 } \\
\text { Saturated zone }\end{array}$}} \\
\hline Uranium-234 & & & & & \\
\hline Uranium-235 & & $\begin{array}{l}6 \\
6\end{array}$ & 6 & $\begin{array}{l}6 \\
6\end{array}$ & $\begin{array}{l}6 \\
6\end{array}$ \\
\hline Uranium-238 & & 6 & $\begin{array}{l}6 \\
6\end{array}$ & $\begin{array}{l}6 \\
6\end{array}$ & $\begin{array}{l}6 \\
6\end{array}$ \\
\hline Actinium-227 & & 20 & $\begin{array}{l}6 \\
20\end{array}$ & $\begin{array}{l}6 \\
20\end{array}$ & $\begin{array}{c}6 \\
20\end{array}$ \\
\hline Protactinium-231 $\mathrm{f}$ & & 50 & $\begin{array}{l}20 \\
50\end{array}$ & $\begin{array}{l}20 \\
50\end{array}$ & \\
\hline Lead-210 & & 100 & $\begin{array}{r}50 \\
100\end{array}$ & & $\begin{array}{c}50 \\
100\end{array}$ \\
\hline Radium-226 $6^{\mathrm{f}}$ & & 70 & 70 & $\begin{array}{r}100 \\
70\end{array}$ & 100 \\
\hline $\begin{array}{l}\text { Radium-226 } \\
\text { Thorium-230 }\end{array}$ & & 60,000 & 60,000 & $\begin{array}{c}70 \\
60.000\end{array}$ & 70 \\
\hline Inhalation rate & $\mathrm{m}^{3} / \mathrm{yr}$ & 8,400 & 8,400 & 60,000 & 60,000 \\
\hline $\begin{array}{l}\text { Inhalation rate } \\
\text { Mass loading for inhalation }\end{array}$ & $g / m^{3}$ & 0.0002 & 0.0002 & 8,400 & 8,400 \\
\hline $\begin{array}{l}\text { Mass loading lor innalation } \\
\text { Occupancy and shielding factor, }\end{array}$ & $-d$ & 0.21 & 0.086 & 0.0002 & 0.0002 \\
\hline external gamma ${ }^{\mathrm{B}}$ & & & & 0.6 & 0.6 \\
\hline Occupancy factor, inhalation ${ }^{a}$ & $-d$ & 0.19 & 0.086 & 0.45 & 0.45 \\
\hline Shape factor, external gamma & $-d$ & 1 & 1 & 1 & 1 \\
\hline $\begin{array}{l}\text { Dilution length for airborne dust, } \\
\text { inhalation }\end{array}$ & $\mathbf{m}$ & 3 & 3 & 3 & 3 \\
\hline Soil ingestion rate & $\mathrm{g} / \mathrm{yr}$ & 36.5 & 36.5 & 36.5 & 36.5 \\
\hline Fruit, vegetable, and grain consumption & $\mathrm{kg} / \mathrm{yr}$ & not used & not used & 160 & 160 \\
\hline Leafy vegetable consumption & $\mathrm{kg} / \mathrm{yr}$ & not used & not used & 14 & 14 \\
\hline Milk consumption & Lyr & not used & not used & 92 & 92 \\
\hline Meat and poultry consumption & $\mathrm{kg} / \mathrm{yr}$ & not used & not used & 63 & 63 \\
\hline Fish consumption & $\mathrm{kg} / \mathrm{yr}$ & not used & not used & 5.4 & 5.4 \\
\hline Other seafood consumption & $\mathrm{kg} / \mathrm{yr}$ & not used & not used & 0.9 & 0.9 \\
\hline Drinking water intake & $\mathrm{L} / \mathrm{yr}$ & not used & not used & 510 & 510 \\
\hline Fraction of drinking water from site ${ }^{a}$ & $-d^{2}$ & not used & not used & 1 & 0 \\
\hline Fraction of aquatic food from site ${ }^{a}$ & $-d$ & not used & not used & 0.5 & 0 \\
\hline Livestock fodder intake for meat & $\mathrm{kg} / \mathrm{d}$ & not used & not used & 68 & 68 \\
\hline Livestock fodder intake for milk & $\mathrm{kg} / \mathrm{d}$ & not used & not used & 55 & 55 \\
\hline Livestock water intake for meat & $\mathrm{L} / \mathrm{d}$ & not used & not used & 50 & 50 \\
\hline Livestock water intake for milk & $\mathrm{L} / \mathrm{d}$ & not used & not used & 160 & 160 \\
\hline Mass loading for foliar deposition & $\mathrm{g} / \mathrm{m}^{3}$ & not used & not used & 0.0001 & 0.0001 \\
\hline Depth of soil mixing layer & $\mathrm{m}$ & 0.15 & 0.15 & 0.15 & 0.15 \\
\hline Depth of roots & $\mathrm{m}$ & not used & not used & 0.9 & 0.9 \\
\hline $\begin{array}{l}\text { Groundwater fractional usage } \\
\text { (balance from surface water) }^{\mathrm{a}}\end{array}$ & $-d$ & & & & \\
\hline Drinking water & & not used & not used & 1 & 0 \\
\hline Livestock water & & not used & not used & 1 & 0 \\
\hline Irrigation & & not used & not used & 1 & 0 \\
\hline Total porosity of the cover material & $\AA^{d}$ & 0.4 & 0.4 & 0.4 & 0.4 \\
\hline $\begin{array}{l}\text { Total porosity of the house or building } \\
\text { foundation }\end{array}$ &.$d$ & 0.1 & 0.1 & 0.1 & 0.1 \\
\hline $\begin{array}{l}\text { foundation } \\
\text { Volumetric water content of the cover } \\
\text { material }\end{array}$ & $-d$ & 0.05 & 0.05 & 0.05 & 0.05 \\
\hline $\begin{array}{l}\text { material } \\
\text { Volumetric water content of the foundation }\end{array}$ & $-d$ & 0.01 & 0.01 & 0.01 & 0.01 \\
\hline
\end{tabular}


TABLE A.1 (Cont.)

\begin{tabular}{|c|c|c|c|c|c|}
\hline \multirow[b]{2}{*}{ Parameter } & \multicolumn{5}{|c|}{ Value } \\
\hline & Unit & Scenario A & Scenario B & Scenario $\mathbf{C}$ & Scenario D \\
\hline Diffusion coefficient for radon gas & $\mathrm{m}^{2} / \mathrm{s}$ & & & & \\
\hline in cover material & & $2.0 \times 10^{6}$ & $2.0 \times 10^{-6}$ & $2.0 \times 10^{-8}$ & $2.0 \times 10^{-6}$ \\
\hline in foundation material & & $2.0 \times 10^{-8}$ & $2.0 \times 10^{-8}$ & $2.0 \times 10^{-8}$ & $2.0 \times 10^{-8}$ \\
\hline in contaminated zone soil & & $2.0 \times 10^{-6}$ & $2.0 \times 10^{-6}$ & $2.0 \times 10^{-6}$ & $2.0 \times 10^{\cdot 6}$ \\
\hline Emanating power of radon gas & $-d$ & 0.2 & 0.2 & 0.2 & 0.2 \\
\hline Racion vertical dimension of $n_{n}$ :xing & $\mathrm{m}$ & 2.0 & 2.0 & 2.0 & 2.0 \\
\hline Average annual wind speed & $\mathrm{m} / \mathrm{s}$ & 2.0 & 2.0 & 2.0 & 2.0 \\
\hline Average building air exchange rate & $1 / \mathrm{h}$ & 1.0 & 1.0 & 1.0 & 1.0 \\
\hline Height of the building (room) & $\mathrm{m}$ & 2.5 & 2.5 & 2.5 & 2.5 \\
\hline $\begin{array}{l}\text { Bulk density of house or building } \\
\text { foundation }\end{array}$ & $\mathrm{g} / \mathrm{cm}^{3}$ & 2.4 & 2.4 & 2.4 & 2.4 \\
\hline Thickness of house or building foundation & $\mathrm{m}$ & 0.15 & 0.15 & 0.15 & 0.15 \\
\hline Building depth below ground surface & $\mathrm{m}$ & 1.0 & 1.0 & 1.0 & 1.0 \\
\hline Fraction of time spent indoors & $-d$ & 0.057 & 0 & 0.5 & 0.5 \\
\hline Fraction of time spent outdoors" & $\therefore$ & 0.171 & 0.086 & 0.25 & 0.25 \\
\hline
\end{tabular}

- Values based on site specifications or scenario assumptions.

b Source: Kautz (1992).

c Based on values in DOE $(1983 a, b)$.

d Parameter is dimensionless.

- Values based on information in NOAA (1982).

r Radionuclide is a decay product. 


\section{APPENDIX REFERENCES}

Kautz, S.A., 1992, technical memo from Kautz (Bechtel/Geotechnical Services, Oak Ridge, Tenn.) to L.G. Jones (Argonne National Laboratory, Argonne, Ill.), March 4.

U.S Department of Energy (DOE), 1983a, Remedial Actions at the Former Vitro Rare Metals Plant Site, Canonsburg, Washington County, Pernsylvania, report DOE/EIS-0096-F, Washington, D.C., July.

U.S. Department of Energy, 1983b. Remedial Action Plan for Stabilization of the Inactive Uranium Mill Tailings Site at Canonsburg, Pennsylvania, report UMTRA-DOE/AL-140, Washington, D.C., Oct.

U.S. National Oceanic and Atmospheric Administration (NOAA), 1982, Climatography of the United States, No. 81, U.S. Department of Commerce, Washington, D.C., Sept. 

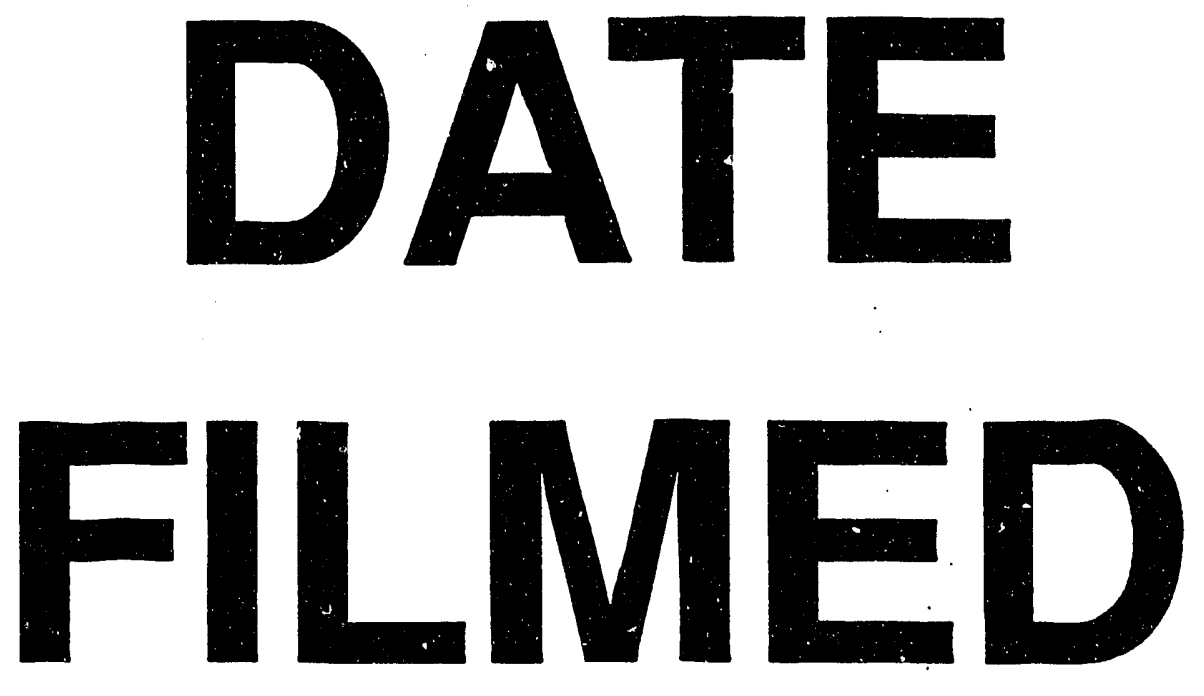

$9 / 22 / 93$
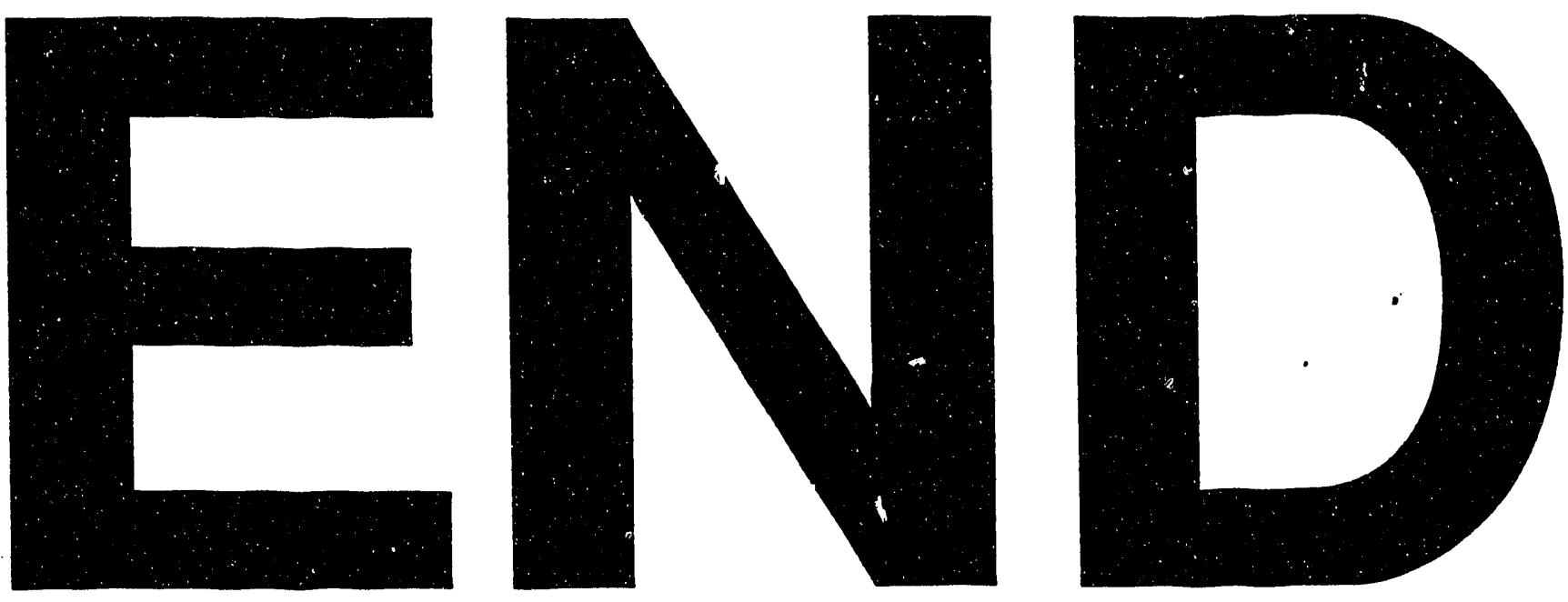


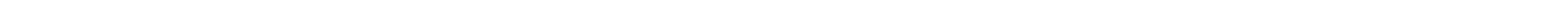

